\section{RMD Open}

Rheumatic \&

Musculoskeletal Diseases

To cite: Merola JF, Espinoza LR, Fleischmann R. Distinguishing rheumatoid arthritis from psoriatic arthritis. RMD Open 2018;4:e000656. doi:10.1136/ rmdopen-2018-000656

- Prepublication history for this paper is available online. To view these files, please visit the journal online (http://dx.doi. org/10.1136/rmdopen-2018000656)

Received 31 January 2018 Revised 25 May 2018 Accepted 25 May 2018
Check for updates

${ }^{1}$ Department of Dermatology, Medicine and Rheumatology, Brigham and Women's Hospital and Harvard Medical School, Boston, Massachusetts, USA ${ }^{2}$ Section of Rheumatology, LSU Health Sciences Center at New Orleans, New Orleans, Louisiana, USA

${ }^{3}$ Department of Medicine, University of Texas Southwestern Medical Center, Metroplex Clinical Research Center, Dallas, Texas, USA

Correspondence to Dr Joseph F Merola; jfmerola@bwh.harvard.edu

\title{
Distinguishing rheumatoid arthritis from psoriatic arthritis
}

\author{
Joseph F Merola, ${ }^{1}$ Luis R Espinoza, ${ }^{2}$ Roy Fleischmann ${ }^{3}$
}

\section{ABSTRACT}

Rheumatoid arthritis (RA) and psoriatic arthritis (PsA) have key differences in clinical presentation, radiographic findings, comorbidities and pathogenesis to distinguish between these common forms of chronic inflammatory arthritis. Joint involvement is typically, but not always, asymmetric in PsA, while it is predominantly symmetric in RA. Bone erosions, without new bone growth, and cervical spine involvement are distinctive of RA, while axial spine involvement, psoriasis and nail dystrophy are distinctive of PsA. Patients with PsA typically have seronegative test findings for rheumatoid factor (RF) and cyclic citrullinated peptide (CCP) antibodies, while approximately $80 \%$ of patients with RA have positive findings for RF and CCP antibodies. Although there is overlap in the pathogenesis of PSA and RA, differences are also present that affect the efficacy of treatment. In PsA, levels of interleukin (IL)-1 $\beta$, IL-6, IL-17, IL-22, IL-23, interferon- $\gamma$ and tumour necrosis factor- $\alpha$ (TNF- $\alpha$ ) are elevated, and in RA, levels of IL-1, IL-6, IL-22, IL-33, TNF- $\alpha$, chemokine ligand 11 and chemokine $\mathrm{C}-\mathrm{X}-\mathrm{C}$ motif ligand 13 are elevated. Differences in the pathogenesis of RA and PsA translate into some variances in the specificity and efficacy of therapies.

\section{INTRODUCTION}

Rheumatoid arthritis (RA) and psoriatic arthritis (PsA) are common chronic inflammatory diseases; both are characterised by pain and swelling in the joints and have significant systemic manifestations. ${ }^{1-3}$ If not diagnosed and treated early, both can lead to joint destruction with loss of function. For this reason, early diagnosis is important to determine therapeutic strategies that will optimise clinical and radiographic outcomes. ${ }^{4}$ Differentiating between RA and PsA can be clinically challenging because there are many similarities in their clinical presentation and manifestations. Both also have similarities with other inflammatory diseases ${ }^{5}$ and association with coprevalent forms of arthritis, such as gout and secondary osteoarthritis. ${ }^{6-8}$

In the last 20 years, biologic diseasemodifying antirheumatic drugs, many with differing mechanisms of action, have become available. These medications target the

\section{Key messages}

What is already known about this subject?

- Rheumatoid arthritis (RA) and psoriatic arthritis (PsA) are both common chronic inflammatory diseases, and differentiation of these conditions can be challenging.

What does this study add?

- We review key differences in clinical, serological, radiographic and pathogenic features of RA and PsA and provide practical guidance for achieving a correct diagnosis.

How might this impact on clinical practice?

- Accurate diagnosis of RA and PSA is important because differences in underlying pathogenesis and response to therapy translate into substantially different clinical outcomes.

disease processes that drive inflammation and joint damage in RA and PsA. However, depending on the molecule, therapeutic selection is complicated by variable efficacy between patients with RA and the manifestations of psoriatic disease (eg, enthesitis or skin psoriasis).

To help practitioners determine an accurate diagnosis, key differences in clinical, serological, radiographic and pathogenic features of RA and PsA are reviewed. The different therapeutic classes that can be of benefit in each disease are discussed in depth.

\section{DIFFERENCES OF RA AND PSA}

RA is an autoimmune systemic inflammatory disease characterised by synovitis, bony erosions and cartilage damage. ${ }^{9} \mathrm{PsA}$ is a heterogeneous autoimmune systemic disease with diverse clinical and radiographic manifestations. ${ }^{9}$ The presence of psoriasis precedes the development of PsA in $85 \%$ of patients, and PsA typically develops about 10 years after the onset of psoriasis. ${ }^{10}$ Other common clinical features of PsA include synovitis with subsequent osteolysis and/or joint fusion of peripheral joints, axial involvement, sacroiliitis, and 


\begin{tabular}{|c|c|c|}
\hline Characteristic & PsA & RA \\
\hline \multicolumn{3}{|l|}{ Clinical } \\
\hline Psoriasis & +++ & - \\
\hline Symmetric joint involvement & + & +++ \\
\hline Asymmetric joint involvement & ++ & + \\
\hline Polyarthritis & ++ & +++ \\
\hline Oligoarthritis/monarthritis & + & + \\
\hline Distal interphalangeal joint involvement & +++ & - \\
\hline Metacarpophalangeal and wrist involvement & +++ & +++ \\
\hline Metatarsophalangeal joint involvement & +++ & +++ \\
\hline Axial spine involvement & +++ & - \\
\hline Cervical spine involvement & + & +++ \\
\hline Enthesitis & +++ & - \\
\hline Dactylitis & +++ & + \\
\hline Synovitis & ++ & +++ \\
\hline Tenosynovitis & ++ & +++ \\
\hline Nail dystrophy & +++ & - \\
\hline Arthritis mutilans & + & - \\
\hline Interstitial lung disease & - & ++ \\
\hline \multicolumn{3}{|l|}{ Serological } \\
\hline Rheumatoid factor & - & +++ \\
\hline Cyclic citrullinated peptide antibodies & $-^{*}$ & +++ \\
\hline $\mathrm{C}$ reactive protein & ++ & +++ \\
\hline Erythrocyte sedimentation rate & ++ & +++ \\
\hline Th17 cell upregulation & ++ & - \\
\hline TNF- $\alpha$-driven & +++ & +++ \\
\hline IL-17A-driven & +++ & - \\
\hline IL-12/23-driven & +++ & - \\
\hline IL-6-driven & - & +++ \\
\hline \multicolumn{3}{|l|}{ Imaging } \\
\hline Pencil-in-cup deformity & ++ & - \\
\hline Ankylosis & ++ & - \\
\hline Subluxation & ++ & ++ \\
\hline Bone proliferation & +++ & - \\
\hline Number of erosions & + & +++ \\
\hline Bone erosion & + & +++ \\
\hline Synovitis & ++ & +++ \\
\hline Tenosynovitis & ++ & +++ \\
\hline Distal interphalangeal joint involvement & +++ & - \\
\hline \multicolumn{3}{|l|}{ Genetic } \\
\hline HLA-B27 alleles & ++ & - \\
\hline HLA-DRB1 alleles & - & ++ \\
\hline
\end{tabular}

The greater number of symbols $(+,++,+++)$ indicates a more common characteristic. The dash $(-)$ indicates the characteristic is not common.

*Approximately $5 \%$ of patients with PsA have seropositive findings for anticyclic citrullinated peptide antibodies. ${ }^{7}$

HLA, human leucocyte antigen; IL, interleukin; PsA, psoriatic arthritis; RA, rheumatoid arthritis; Th17, Thelper 17; TNF, tumournecrosis factor.

extra-articular manifestations, including nail dystrophy, enthesitis and dactylitis; not all are present in every patient. Key clinical, serological and radiographic differences between RA and PsA are summarised in table 1.

\section{Epidemiological characteristics of RA and PsA}

RA is more common than PsA, affecting more than 1 million in the USA. ${ }^{11}$ PsA affects roughly half a million people in the USA ${ }^{12}$ and approximately $30 \%$ of patients with psoriasis. ${ }^{13}$ Worldwide prevalence estimates for RA and PsA are variable. In many populations, RA prevalence is estimated to be $0.5 \%-1.0 \%$; however, prevalence is much higher in Native American Indian populations ( $\sim 5 \%$ to $7 \%)$ but lower in China and Japan ( 0.2\% to $0.3 \%) .{ }^{14-19}$ PsA prevalence estimates in the USA and Europe range from $0.1 \%$ to $0.4 \%$, whereas in Japan, PsA prevalence is lower. ${ }^{12} 2021$ This variability in prevalence suggests that both environmental and genetic factors affect risk for disease.

\section{Pathogenesis of RA and PsA}

A combination of genetic factors and environmental triggers is thought to elicit autoimmune inflammatory responses in both RA and PsA. The pathogenesis of RA and PsA is not completely understood. In addition to the known association with human leucocyte antigen (HLA)-DR4 in RA, one theory is the development of lung inflammation, typically prior to joint symptoms, with production of antibodies to citrullinated protein antigens that mediate pathogenesis. ${ }^{22}{ }^{23}$ Gut dysbiosis has been linked with the pathogenesis of PsA. ${ }^{24}$ While there is some overlap in the development of inflammation in PsA and RA, some important differences are evident. ${ }^{25}$ For example, in both PsA and RA, HLA alleles have been shown to affect disease susceptibility and severity; however, the primary genotypes associated with each disease are different. In PsA, HLA-B27 is associated with the development of enthesitis and symmetric sacroiliitis, and HLA-B08 is associated with joint fusion, asymmetric sacroiliitis and dactylitis. ${ }^{26}$ In RA, HLA-DRB1 alleles are associated with disease susceptibility and severity in patients who have positive findings for rheumatoid factor (RF) and cyclic citrullinated peptide (CCP) antibodies. ${ }^{27}$

In both PsA and RA, inflammatory responses are characterised by the increased production of proinflammatory molecules that act in synergy to propagate chronic inflammation (figure 1). ${ }^{25} 2829$ In PsA, activated T cells and macrophages induce production of inflammatory chemokines and cytokines, including interleukin (IL)-17, IL-23, IL-22, IL-1 $\beta$, IL-6, interferon- $\gamma$ and tumour necrosis factor- $\alpha$ (TNF- $\alpha) .{ }^{29}{ }^{30}$ Specifically, elevated levels of IL-17 + CD8+ T cells have been observed in the joints of patients with PsA but not in those with RA. ${ }^{31}$ In addition, recent studies have implicated increased expression of IL-9 and its receptor (IL-9R) in the promotion of pathological T-cell growth and subclinical gut inflammation. $^{32} 33$

Key cytokines identified as being associated with joint damage and radiographic progression of RA include TNF- $\alpha$, IL-6, IL-1, IL-22, IL-33, chemokine ligand 11 and chemokine C-X-C motif ligand $13 .{ }^{25}$ Certain cytokines and chemokines are present at higher levels in 


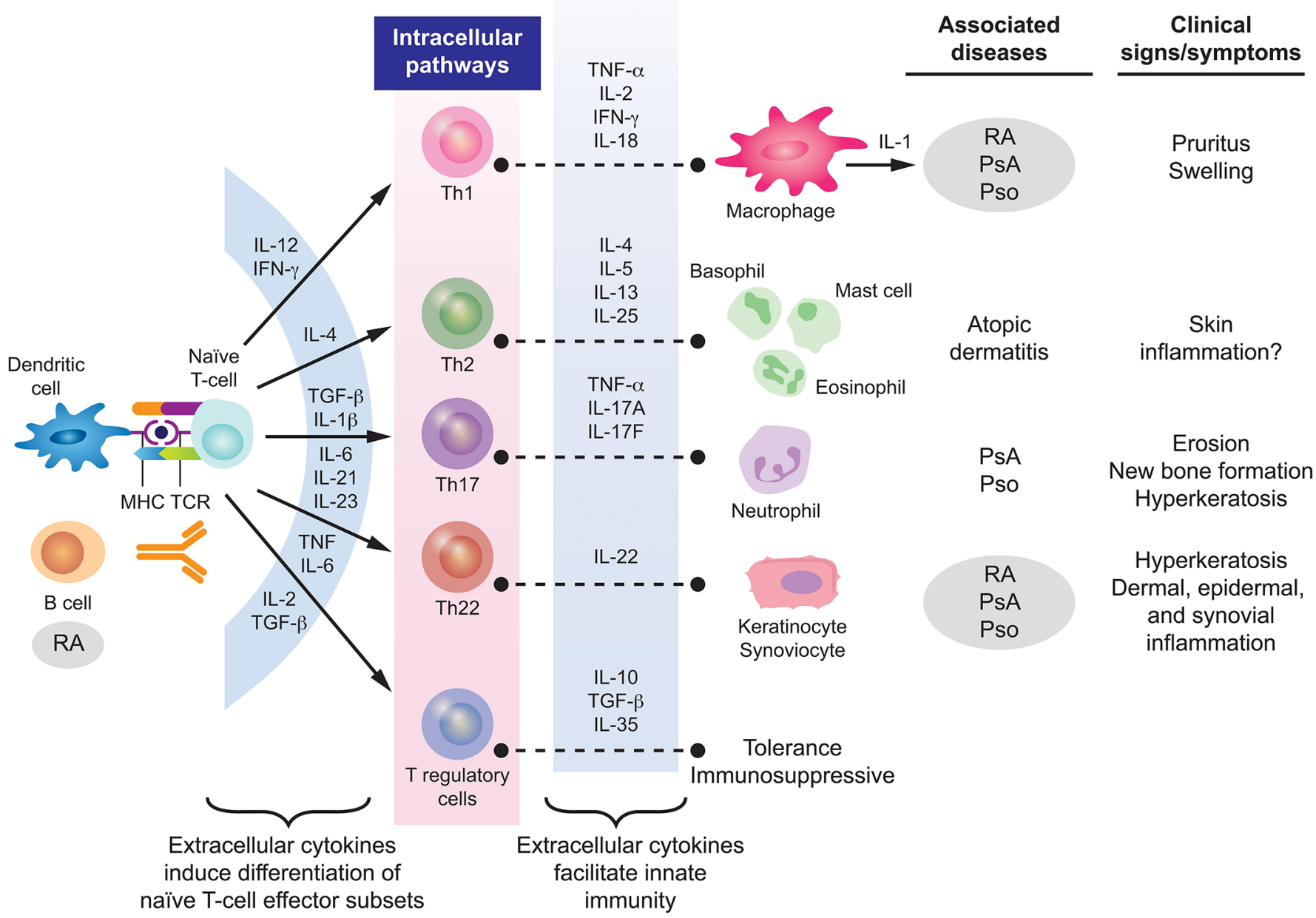

Figure1 Pathogenesisof PsA and RA. Reprinted from Coates et al ${ }^{29}$ and Perera et al. ${ }^{28} \mathrm{IFN}$, interferon; IL, interleukin; MHC, major histocompatibility complex; PsA, psoriatic arthritis; Pso, psoriasis; RA, rheumatoid arthritis; TCR, T cell receptor; TGF- $\beta$, transforming growth factor- $\beta$; Th, T helper; TNF- $\alpha$, tumour necrosis factor- $\alpha$.

patients with polyarticular versus oligoarticular arthritis, suggesting that they could be markers of disease severity and/or progression. ${ }^{25}$ In addition, it has been hypothesised that the onset of RA may be triggered in some patients by autoimmune responses (eg, elevated CCP levels) in the lungs. Smoking, infections or air pollution exposure may trigger local inflammation in the lungs, promoting protein citrullination and stimulating CCP production. ${ }^{34}$

\section{Clinical characteristics of RA and PsA}

For RA, the American College of Rheumatology (ACR) / European League Against Rheumatism classification criteria were designed for patient characterisation and use in clinical trials. ${ }^{36}$ The key clinical characteristic is the confirmation of definite, persistent, clinical synovitis in at least one joint. The criteria include the number of joints involved, duration of symptoms, and the demonstration of serological markers and an elevated acute-phase reactant. For PsA, the Classification Criteria for Psoriatic
Arthritis help categorise patients with inflammatory articular disease for clinical trials. ${ }^{37}$ Key clinical characteristics include a personal or family history of psoriasis, psoriatic nail dystrophy and dactylitis. Neither classification criteria should be confused as diagnostic criteria.

Joint involvement is predominantly symmetric in RA and often, but not always, asymmetric in PsA. ${ }^{25} 3839$ In both RA and PsA, most patients have polyarthritis $(\geq 5$ involved joints), although joint involvement can be oligoarticular or polyarticular. ${ }^{5} 25263940$ Monoarticular disease is less common in PsA; however, $5 \%-10 \%$ of patients may present with isolated distal joint involvement. ${ }^{5}$ In PsA, prognosis worsens and symmetry of joint involvement tends to increase as the number of affected joints increases. ${ }^{51}$

Typically, RA affects the shoulder, elbow, wrist, metacarpophalangeal, proximal interphalangeal, hip, knee, ankle and metatarsophalangeal joints. In PsA, the distal interphalangeal joints of the hands and feet, large joints 
of the lower extremities, the axial spine and sacroiliac joints are commonly affected; the metacarpophalangeal and metatarsophalangeal joints and wrist can be involved as well. PsA, rather than RA, is included in the spectrum of spondyloarthritis as PsA can affect the axial skeleton (eg, sacroiliac joints and spine).$^{26}{ }^{38}$ It is estimated that up to $50 \%$ of patients with PsA experience inflammation in the axial skeleton ${ }^{42}$; axial involvement can be a differentiating feature of PsA because it is not present in RA other than cervical spine involvement, which has been reported in up to $80 \%$ of patients with RA. ${ }^{43}$

Although TNF- $\alpha$ induces angiogenesis in both RA and PsA,${ }^{44}$ differences in synovial vascularity can help differentiate the diseases. Both RA and PsA exhibit proliferation of endothelial cells, but topological differences in endothelial cells suggest differing pathological features. ${ }^{45}$ Among patients with knee synovitis, straight, branching vessels are observed in RA, and predominantly tortuous, bushy vessels are observed in PsA. ${ }^{46}$ These physiological differences may be caused by varied patterns of synovial cytokine expression as significantly higher levels of IL-1 $\beta$, IL-2, IL-10 and IFN- $\gamma$ are found in PsA synovial explants compared with RA synovial explants. ${ }^{47}$

Enthesitis (inflammation of entheses at sites where ligaments or tendons insert into the bone) occurs in $35 \%$ of patients with $\mathrm{PsA}^{48}$ but is uncommon in patients with RA. ${ }^{39}$ Enthesitis is proposed to have a key role in the pathogenesis of $\mathrm{PsA}^{49}$ and the presence of enthesitis can be particularly valuable in differentiating PsA from RA. The most common locations of enthesitis in patients with PsA are the insertion sites of the plantar fascia, the Achilles tendon and ligamentous attachments of the knee. ${ }^{50}$ In rare cases, enthesitis may be the only manifestation of PsA. Signs and symptoms of enthesitis can be non-specific and difficult to distinguish from other inflammatory conditions, particularly fibromyalgia, in the absence of other manifestations common to PsA. ${ }^{40}$

Dactylitis (inflammation of an entire digit) is a common manifestation of PsA that affects up to $50 \%$ of patients, compared with approximately $5 \%$ of patients with RA. ${ }^{59}$ Dactylitis may also occur in patients with other forms of spondyloarthritis, such as ankylosing spondylitis and reactive arthritis, but also occasionally in gout and sarcoidosis. ${ }^{5651}$ However, dactylitis is a fairly specific sign of PsA that can aid in the differential diagnosis, especially when it is present along with enthesitis.

Nail dystrophy, which is characterised by onycholysis, pitting and hyperkeratosis, is an important clinical manifestation of PsA. In a prospective study characterising the clinical presentation of early PsA, $67 \%$ of patients had nail dystrophy; the incidence was higher $(80 \%)$ in patients with distal interphalangeal joint involvement. ${ }^{52}$ The increased incidence of nail disease in patients with distal interphalangeal joint involvement has been attributed to the topographic association between the extensor tendon enthesis and the nail. ${ }^{53}$ Thus, the presence of nail lesions can be especially helpful in differentiating
PsA from other forms of spondyloarthritis, RA, gout and osteoarthritis.

Ocular disorders are common extra-articular manifestations of RA and PsA. ${ }^{55}$ The most common ocular manifestation of RA is keratoconjunctivitis sicca, which affects approximately $18 \%$ of patients; other common eye disorders in patients with RA include episcleritis $(5 \%)$ and scleritis $(2 \%) .{ }^{56}$ Uveitis occurs in PsA, affecting approximately $7 \%$ of patients and is more common in women than men; the incidence is far higher in patients with axial disease and HLA-B27 positivity. ${ }^{54}$ 57-59 In patients with PsA or inflammatory bowel disease, uveitis is typically bilateral with an insidious onset, affecting the anterior and intermediate layers of the eye. ${ }^{54}$

Cutaneous manifestations are common in both RA and PsA. The most common cutaneous features of RA include rheumatoid nodules, vasculitic skin lesions and granulomatous dermatoses. ${ }^{60-62}$ Current psoriasis is an important clinical finding in a patient with arthritis. Skin disease precedes the development of joint symptoms in $84 \%$ of patients with PsA, and up to $96 \%$ of patients with PsA have either current or previous psoriasis or family history of psoriasis. ${ }^{63}$ Compared with patients with psoriasis but without PsA, patients with PsA have more extensive psoriasis and higher rates of pustular and inverse psoriasis. ${ }^{64}$ In addition, patients with scalp psoriasis, inverse psoriasis and nail dystrophy are at increased risk for PsA. ${ }^{65}$ It is important to remember that manifestations of psoriasis are not always overt, and patients with seronegative inflammatory arthritis should be evaluated for scalp, inverse, genital, palmoplantar and nail psoriasis. Furthermore, inverse psoriasis is traditionally under-recognised, and recent findings indicate a greater prevalence of inverse psoriasis than commonly appreciated. ${ }^{66}$ With such a thorough physical examination, many patients with 'seronegative' RA are correctly identified as actually having PsA.

\section{Serological features of RA and PsA}

RA is a seropositive arthropathy, with approximately $80 \%$ of patients having a positive test result for RF or CCP antibodies. ${ }^{3967} \mathrm{CCP}$ antibodies are a more specific marker for RA than RF, but both biomarkers are considered to be distinct and complementary predictors of disability and joint erosion. ${ }^{68} 69$

In contrast, PsA is a seronegative inflammatory arthropathy. RF and CCP are absent in most patients with PsA, and if patients do have positive test findings for RF or CCP, the titres are usually low. ${ }^{239670}$ In a study comparing patients with RA or PsA and controls, the mean RF and anti-CCP titre values were substantially higher in patients with RA compared with PsA (RF titre: 56 vs $11 \mathrm{U} / \mathrm{mL}$; anti-CCP titre: 14 vs $2 \mathrm{U} / \mathrm{mL}) .{ }^{67}$ Titres in patients with PsA were similar to values in controls. ${ }^{67}$ Although the presence of serum RF or CCP antibodies is generally not used to exclude diagnosis of non-rheumatic diseases (eg, fungal infections), data suggest that at anti-CCP titre values $\geq 11.6 \mathrm{U} / \mathrm{mL}$, it is highly probable that patients 
have RA rather than PsA. ${ }^{67}$ In both patients with RA and PsA, the presence of anti-CCP antibodies is associated with bone destruction, suggesting that the osteocatabolic effect of anti-CCP antibodies is not found only in RA as previously thought. ${ }^{71}$

$C$ reactive protein (CRP) and erythrocyte sedimentation rate (ESR) are markers of acute-phase inflammatory responses in patients with RA and PsA, but more so in patients with RA. ${ }^{3670}$ In a systematic literature review of RA disease activity parameters, ESR and CRP levels were a significant predictor of radiographic progression in most studies. ${ }^{72}$ The acute-phase response is correlated with synovial inflammation, radiographic disease progression and erosive joint damage. ${ }^{25}$ On average, patients with PsA have significantly lower CRP and ESR levels than patients with RA. ${ }^{73}$ However, elevated ESR and CRP levels are significantly correlated with the number of swollen joints and with ultrasound abnormalities in PsA. ${ }^{73-75}$ ESR, in particular, is considered to be one of the best predictors of damage progression in PsA. It has been suggested that a low ESR is protective, while rates $>15 \mathrm{~mm}$ /hour are associated with increased risk for mortality. ${ }^{70}$ Changes in ESR and CRP correspond with clinical outcomes and can be used to track response to treatment. ${ }^{73}$

Increased ESR and CRP levels are markers of inflammation, but not necessarily just in RA. ${ }^{76}$ Other rheumatological diseases associated with elevated ESR and CRP levels include polymyalgia rheumatica, Sjögren's syndrome and ankylosing spondylitis. ${ }^{76}$

\section{Radiographic features of RA and PsA}

Use of imaging can provide important information to help practitioners identify and differentiate between types of inflammatory arthritis. Conventional radiography can be used to identify juxta-articular bony proliferations, which can be used to help discern PsA from other types of inflammatory arthritis, and to visualise osteodestructive lesions characteristic of RA. ${ }^{77}$ Other characteristic radiographic changes observed in patients with severe PsA (including arthritis mutilans) are bone resorption, pencil-in-cup deformities and ankylosis. ${ }^{26}$ However, conventional radiographs are not as sensitive as ultrasound or MRI for detection of bone erosions and may not help clinicians detect soft-tissue changes well. ${ }^{78}$ Additionally, in our experience, radiologists will often report changes consistent with osteoarthritis in patients with PsA, and it is necessary for rheumatologists to interpret these findings in the proper clinical context.

Ultrasound imaging can be used to identify characteristic features of inflammatory arthritis, including enthesitis, cortical bone erosions, cartilage lesions, synovitis and tenosynovitis. ${ }^{78}$ Bone erosions are an important diagnostic criterion of RA that can be identified based on intra-articular discontinuity of the bone surface. ${ }^{78} 79$ Ultrasound evaluations of bone erosions are more reliable for joints that are easily accessible (eg, small joints of hands or feet) than for carpal or tarsal bones, which cannot be viewed circumferentially. ${ }^{78}$
Interestingly, while clinical signs of enthesitis are a hallmark of PsA, the presence of enthesitis on ultrasound cannot always help clinicians distinguish PsA from RA. ${ }^{80}$ In an evaluation of the Leeds Enthesitis Index, greyscale and power Doppler techniques could not help distinguish between PsA and RA based on features of enthesitis, possibly because ultrasound imaging cannot visualise bone oedema, which may cause entheseal tenderness, or because of a higher prevalence of juxta-articular inflammation in RA. ${ }^{80}$ However, it has been observed that central slip enthesitis at the proximal interphalangeal joints is present on ultrasound in about $25 \%$ of patients with PsA but absent in patients with RA, potentially serving as a distinguishing feature of PsA versus RA in some patients. ${ }^{1}$

Ultrasound imaging can be used to identify characteristic joint involvement that distinguishes PsA from RA. For example, distal interphalangeal joint changes are found almost exclusively in patients with PsA compared with those with RA, ${ }^{81}$ and dactylitis due to flexor tenosynovitis is characteristic of PsA. ${ }^{81-83}$ While overall prevalence of synovitis is higher in RA $(\sim 90 \%$ of affected joints) than in PsA ( $60 \%$ of affected joints), peritendon extensor digitorum tendon inflammation is significantly more common in early PsA than in early RA $54.1 \%$ vs $2.5 \%) .{ }^{1}$ It can be difficult to differentiate between types of inflammatory arthritis based on bone changes observed on ultrasound; however, cortical irregularity from periosteal new bone formation is suggestive of PsA. ${ }^{84}$

MRI can be used to identify joint synovitis, bone and joint erosions, bone marrow oedema, spondylitis, periarticular inflammation, active enthesitis, nail disease and periostitis. ${ }^{85} 86$ The location of bone marrow oedema can help differentiate between PsA (near entheses) and RA (near capsular attachments), and diaphyseal bone marrow oedema is a characteristic feature of early PsA. ${ }^{87}$ As with ultrasound, on MRI, distal interphalangeal joint erosions and hypertrophic bone changes are characteristic findings in PsA that may help differentiate it from RA. Tenosynovitis is another common MRI observation in inflammatory arthritis; in RA, tenosynovitis is most common in the hands and wrists, whereas in PsA softtissue inflammation around the tendon sheath is characteristic of dactylitis. ${ }^{86}$ MRI is also useful for identifying patients that will develop onychopathy, a characteristic of psoriatic nail dystrophy. ${ }^{85}$

\section{Comorbidities occurring in RA and PsA}

Differences in patient comorbidities may help clinicians differentiate between RA and PsA (table 2). Overall, comorbidity burden may be higher in RA than in PsA, but both diseases are similarly associated with increased risk for comorbidities linked to systemic inflammation (eg, cardiovascular disease). ${ }^{29}{ }^{88}$ Han and colleagues ${ }^{89}$ found that patients with RA and PsA had similarly increased prevalence ratios of ischaemic heart disease, atherosclerosis, peripheral vascular disease, congestive heart failure, cerebrovascular disease, hyperlipidaemia and hypertension compared with healthy controls. However, 


\begin{tabular}{|c|c|c|}
\hline Comorbidity & PsA & RA \\
\hline Thyroid disorders & - & $\checkmark$ \\
\hline Infections & - & $\checkmark$ \\
\hline Osteoporosis & - & $\checkmark$ \\
\hline Lymphoma & - & $\checkmark$ \\
\hline Haematopoietic malignancies & - & $\checkmark$ \\
\hline Skin cancer & - & $\checkmark$ \\
\hline Cataracts/glaucoma & - & $\checkmark$ \\
\hline Uveitis & $\begin{array}{l}\text { SpA with axial } \\
\text { involvement and/or } \\
\text { HLA-B27 positivity }\end{array}$ & - \\
\hline IBD & $\begin{array}{l}\text { SpA with axial } \\
\text { involvement }\end{array}$ & - \\
\hline Psoriasis & $\checkmark$ & - \\
\hline Overweight/obese & $\checkmark$ & - \\
\hline Diabetes mellitus & $\checkmark$ & - \\
\hline Metabolic syndrome & $\checkmark$ & - \\
\hline Hypertriglyceridaemia & $\checkmark$ & - \\
\hline Anxiety and depression & $\checkmark$ & - \\
\hline NAFLD & $\checkmark$ & - \\
\hline Hypertension & - & - \\
\hline Hyperlipidaemia & - & - \\
\hline
\end{tabular}

HLA, human leucocyte antigen; IBD, inflammatory bowel disease; NAFLD, non-alcoholic fatty liver disease; PsA, psoriatic arthritis; RA, rheumatoid arthritis; SpA, spondyloarthritis.

registry data suggest that the rates of obesity, diabetes mellitus and metabolic syndrome are significantly higher in patients with PsA compared with those with RA. ${ }^{90}$ Notably, most patients with PsA are overweight or obese. ${ }^{90}$ Cardiometabolic comorbidities of PsA are associated with higher levels of systemic inflammation and increased disease severity. ${ }^{91}{ }^{92}$ In addition, psoriatic skin lesions are associated with an increased risk for cardiovascular disease and mortality. ${ }^{93}{ }^{94}$ Of interest, PsA is an independent predictor of non-alcoholic fatty liver disease (NAFLD) in patients with psoriasis, while in patients with $\mathrm{RA}$, the rates of NAFLD are similar to those observed in the general population. ${ }^{29} 95$

\section{Treatment options for RA and PsA}

Because of the differences in disease pathogenesis, clinical manifestations and response to therapy between RA and PsA, treatment strategies may differ. Table 3 provides a summary of current Food and Drug Administration (FDA)-approved treatments for RA and PsA. Agents targeting more upstream factors (eg, TNF- $\alpha$ ) are effective in both PsA and RA, while agents targeting more downstream cytokines are more disease-specific, demonstrating significant efficacy in either RA (eg, IL-6) or PsA (eg, IL-17A), but not in both diseases.
Table 3 FDA-approved therapies for PsA or RA

\begin{tabular}{|c|c|c|c|}
\hline \multirow[b]{2}{*}{ Class } & \multirow[b]{2}{*}{ Available agent } & \multicolumn{2}{|c|}{ Indication } \\
\hline & & PsA & RA \\
\hline \multicolumn{4}{|c|}{ Conventional synthetic DMARDs } \\
\hline & Methotrexate & * & $\checkmark$ \\
\hline & Leflunomide & - & $\checkmark$ \\
\hline & Corticosteroids & $\sqrt{ } \dagger$ & $\checkmark$ \\
\hline & Hydroxychloroquine & - & $\checkmark$ \\
\hline & Sulfasalazine & * & $\checkmark$ \\
\hline & Ciclosporin & * & $\sqrt{ } \ddagger$ \\
\hline \multicolumn{4}{|l|}{ Biological DMARDs } \\
\hline \multirow[t]{5}{*}{ TNF- $\alpha$ inhibitors } & Etanercept & $\checkmark$ & $\checkmark$ \\
\hline & Infliximab & $\checkmark$ & $\checkmark$ \\
\hline & Adalimumab & $\checkmark$ & $\checkmark$ \\
\hline & Golimumab & $\checkmark$ & $\checkmark$ \\
\hline & Certolizumab pegol & $\checkmark$ & $\checkmark$ \\
\hline \multirow[t]{2}{*}{ IL-17A inhibitor } & Secukinumab & $\checkmark$ & - \\
\hline & Ixekizumab & $\checkmark$ & - \\
\hline IL-12/23 inhibitor & Ustekinumab & $\checkmark$ & - \\
\hline \multirow[t]{2}{*}{$\begin{array}{l}\text { IL-6 receptor } \\
\text { inhibitors }\end{array}$} & Tocilizumab & - & $\checkmark$ \\
\hline & Sarilumab & - & $\checkmark$ \\
\hline $\begin{array}{l}\mathrm{IL}-1 \text { receptor } \\
\text { antagonist }\end{array}$ & Anakinra & - & $\checkmark$ \\
\hline $\begin{array}{l}\text { T-cell activation } \\
\text { inhibitor }\end{array}$ & Abatacept & $\checkmark$ & $\checkmark$ \\
\hline CD20 inhibitor & Rituximab & - & $\checkmark$ \\
\hline
\end{tabular}

Targeted synthetic oral small-molecule DMARDs

\begin{tabular}{llll} 
PDE4 inhibitor & Apremilast & $\checkmark$ & - \\
Janus kinase inhibitor Tofacitinib & $\checkmark$ & $\checkmark$ \\
\hline
\end{tabular}

${ }^{*}$ Commonly used off-label.

†Discontinuation of systemic corticosteroids can cause serious psoriasis flare and dosing should be tapered instead of abruptly stopped.

$\ddagger$ Ciclosporin is not commonly used in RA.

$\mathrm{CD}$, cluster of differentiation; DMARD, disease-modifying antirheumatic drug; FDA, Food and Drug Administration; IL, interleukin; PDE4, phosphodiesterase 4; PsA, psoriatic arthritis; RA, rheumatoid arthritis; TNF, tumour necrosis factor.

Conventional synthetic disease-modifying antirheumatic drugs

Methotrexate is the most frequently used conventional synthetic disease-modifying antirheumatic drug (csDMARD) for the treatment of RA, and its efficacy is well-established in this patient population. ${ }^{96}$ Data on the use of methotrexate in PsA are more mixed, and it is believed that, generally, methotrexate is not effective for every clinical domain affected by PsA. ${ }^{97}$ No benefit was observed with methotrexate compared with placebo in a randomised, placebo-controlled trial in $\mathrm{PsA}^{98}{ }^{9}$ but this trial 
has been heavily criticised as it was underpowered and used a suboptimal dose of methotrexate. However, a benefit of methotrexate monotherapy was observed in the 'tight control of psoriatic arthritis' study. ${ }^{99}$ Although methotrexate has not been studied in large-scale controlled trials in PsA and the studies that have been conducted using methotrexate have likely underestimated its efficacy because of limitations of study designs, real-world data indicate that the efficacy of methotrexate in PsA may be comparable with that in RA. ${ }^{96}{ }^{100}$ In addition, methotrexate is associated with reductions in disease activity and improvements in health-related quality of life in patients with PsA and RA. ${ }^{96}$ While leflunomide has shown efficacy in patients with PsA compared with placebo, it is only FDA-approved for the treatment of patients with RA in the USA. ${ }^{101}$

\section{Biologic disease-modifying antirheumatic drugs \\ TNF- $\alpha$ inhibitors}

TNF- $\alpha$ is a proinflammatory cytokine that is overexpressed in the synovium of patients with inflammatory arthritis. Currently, five TNF- $\alpha$ inhibitors (etanercept, infliximab, adalimumab, golimumab and certolizumab pegol) have been FDA-approved for the treatment of both RA and PsA in the USA.

In RA, a consequence of TNF- $\alpha$ inhibition, in addition to inhibiting systemic inflammation, is to inhibit bone erosion and reduce structural damage by inhibiting osteoclast formation. The ability of TNF- $\alpha$ inhibitors to block induction of matrix metalloproteinases and aggrecanases has been postulated to reduce destruction of the cartilage matrix. ${ }^{102} 103$ Across clinical studies in RA, the five available TNF- $\alpha$ inhibitors have provided strikingly similar improvements in ACR20, ACR50 and ACR70 response rates, reductions in structural damage, and improvements in quality of life. ${ }^{104-111}$

In PsA, TNF- $\alpha$ inhibitors reduce synoviocyte hyperproliferation and decrease T-cell and macrophage infiltration, reducing synovial thickness. ${ }^{112-115}$ Similar to their actions in RA, TNF- $\alpha$ inhibitors modulate angiogenesis and osteoclastogenesis and reduce synovitis in PsA. ${ }^{113114116}$ They have also been shown to improve signs and symptoms of enthesitis, dactylitis, axial involvement and skin disease, and evidence suggests that TNF- $\alpha$ inhibition slows radiographic disease progression. ${ }^{117-119}$

\section{IL-17A inhibitors}

IL-17A is a proinflammatory effector cytokine produced by $\mathrm{T}$ helper (Th) 17 cells, macrophages, mast cells, dendritic cells, natural killer cells and CD8+ T cells. ${ }^{120-125}$ Synovial fluid levels of IL-17A are increased in patients with PsA, and studies have shown that this cytokine plays a role in pathogenic angiogenesis, osteoclastogenesis and fibrogenesis. ${ }^{31}{ }^{126-128}$ IL-17A interactions with synovial-like fibroblasts, osteoblasts and osteoclast precursors promote chronic inflammation and bone changes that contribute to joint damage in PsA. ${ }^{129-131}$ Like TNF- $\alpha$, IL-17 can also induce osteoclastogenesis and upregulate matrix metalloproteinases and other proinflammatory cytokines. ${ }^{31} \mathrm{In}$ patients with PsA, the presence of IL-17-producing T cells is associated with disease activity measures (ie, CRP and ESR) and radiographic erosion. ${ }^{31}$

The IL-17A inhibitors secukinumab and ixekizumab have been FDA-approved for the treatment of active PsA. In clinical studies, treatment with secukinumab and ixekizumab improved signs and symptoms of disease, inhibited radiographic progression of joint damage, and improved physical functioning and quality of life in patients with active PsA. ${ }^{132-134}$ In addition, secukinumab and ixekizumab were efficacious in patients who were naive to TNF- $\alpha$ inhibitors, had an inadequate response to TNF- $\alpha$ inhibitors, or stopped treatment because of safety or tolerability reasons. ${ }^{133} 135136$

Enhanced expression of IL-17A is a characteristic feature in the joints of patients with PsA but not RA. Consistent with this finding, clinical studies of IL-17A inhibitors in RA have shown that these agents have limited therapeutic efficacy. ${ }^{137-139}$

\section{IL-12 and IL-23 dual inhibitor}

IL-12 and IL-23 are signature cytokines involved in the pathogenesis of psoriasis and PsA. IL-12 stimulates Th1 cells and is produced by monocytes and macrophages in response to inflammation, and IL-23 is an upstream cytokine produced predominantly by myeloid dendritic cells to regulate Th17 cell function. ${ }^{140-144}$ IL-12 promotes continued Th1 differentiation, inflammation and activation of natural killer cells, and IL-23 is involved in the pathogenic processes related to osteoclastogenesis and bone erosion. ${ }^{140} 145-147$

The IL-12/23p40 subunit inhibitor, ustekinumab, blocks Th1 and Th17 differentiation and downstream production of IL-17. In phase III clinical trials, ustekinumab significantly reduced radiographic progression of joint damage and improved signs and symptoms of disease in patients with active PsA. ${ }^{148} 149$ Ustekinumab has not demonstrated efficacy in patients with RA. ${ }^{150}$ An IL-23-specific inhibitor, guselkumab, was also not efficacious in patients with $\mathrm{RA}^{151}$; however, preliminary data of this agent in patients with PsA indicate improvement in joint symptoms. ${ }^{152}$ Another IL-23-specific inhibitor, risankizumab, showed positive results in a phase II study of PsA. ${ }^{153}$

\section{IL-6 inhibitors}

IL-6 is a proinflammatory cytokine produced by macrophages and $\mathrm{T}$ cells during acute-phase inflammatory responses. Along with transforming growth factor- $\beta$ and IL-23, IL-6 contributes to maintenance of pathogenic Th17 cell differentiation and IL-17 production. ${ }^{.44} 154155$

Elevated synovial levels of IL-6 have been observed in patients with active RA and PsA. ${ }^{156} 157$ In RA, IL-6 is believed to upregulate the expression of endothelial adhesion molecules during osteoclast maturation and bone erosion. ${ }^{157}$ In PsA, IL-6 is produced by activated Th17 cells, inducing expression of IL-12 and IL-23, which 
stimulate differentiation of Th1 and Th17 cells and promote a cycle of inflammation. ${ }^{157}$

The IL-6 inhibitors tocilizumab and sarilumab are FDA-approved for the treatment of RA and reduce disease activity and radiographic joint damage ${ }^{157}$ Other IL-6 inhibitors (eg, olokizumab) are in development for the treatment of RA. ${ }^{157}$

In a phase IIb study of PsA, the IL-6 inhibitor clazakizumab failed to show a dose response. ${ }^{158}$ Additionally, case reports have suggested that tocilizumab may be efficacious for the treatment of refractory PsA. ${ }^{159}$

\section{IL-1 receptor antagonists}

IL-1 cytokines induce synovial inflammation and mediate bone resorption and cartilage destruction through interactions with prostaglandin $\mathrm{E}_{2}$ and proteases, such as matrix metalloproteinases. ${ }^{16011^{2} 1}$ The IL-1 receptor antagonist, anakinra, is FDA-approved for the treatment of RA; however, it is not as effective as TNF- $\alpha$ inhibitors in most patients. ${ }^{157}$ The results of clinical studies of anakinra in spondyloarthropathies have been disappointing. ${ }^{162}$

\section{T-cell activation inhibitors}

Abatacept is a fusion protein construct that inhibits T-cell activation by binding to CD80/CD86 ligands on the surface of antigen-presenting cells, thereby reducing proinflammatory cytokine and autoantibody levels. It is FDA-approved for the treatment of active RA and is efficacious in patients with RA and inadequate response to methotrexate ${ }^{163}$ or TNF- $\alpha$ inhibitors. ${ }^{164}$ Abatacept is also FDA-approved for the treatment of active PsA. A phase III study recently demonstrated the efficacy of abatacept regardless of prior TNF- $\alpha$ inhibitor exposure. In patients with both psoriasis and PsA, no benefit was observed in skin symptoms compared with placebo. ${ }^{165}$

\section{CD20 inhibitors}

In RA, B cells produce autoantibodies and a range of cytokines, and express receptor activator of nuclear factor $\kappa B$ ligand (RANKL), which upregulates osteoclast differentiation and activation. ${ }^{166}$ CD20 molecules are expressed on B cells, and inhibition of these molecules results in B cell depletion and direct downregulation of RANKL and proinflammatory cytokines. ${ }^{38} 166$

The CD20 inhibitor, rituximab, is FDA-approved for the treatment of RA in combination with methotrexate for patients with insufficient response to TNF- $\alpha$ inhibitors. In clinical studies of patients with RA, rituximab plus methotrexate was effective in reducing progression of joint damage. ${ }^{166}$ However, probably because patients with PsA generally lack circulating autoantibodies, rituximab has not been shown to be effective in PsA. ${ }^{38}$

\section{Targeted synthetic oral small-molecule disease-modifying} antirheumatic drugs

Phosphodiesterase-4 inhibitors

Phosphodiesterase-4 (PDE4) is an enzyme that promotes the degradation of cyclic adenosine monophosphate, thereby upregulating inflammatory responses by increasing levels of cytokines, including TNF- $\alpha$, IL-12 and IL-23. ${ }^{167}$ The PDE4 inhibitor, apremilast, is FDAapproved for the treatment of active PsA based on results from phase III clinical studies showing that treatment reduced measures of disease activity and improved clinical outcomes. ${ }^{168} 169$ No studies are available that evaluate the ability of apremilast to suppress radiographic progression.

In animal models of RA, apremilast was shown to inhibit TNF- $\alpha$ release from human rheumatoid synovial membrane cultures and reduce clinical disease activity. ${ }^{170}$ However, a phase II study in patients with RA failed to show efficacy of apremilast compared with placebo. ${ }^{171}$

\section{Janus kinase inhibitors}

Janus kinases (JAKs) are cytoplasmic tyrosine kinases that regulate cytokine signalling pathways involved in inflammatory responses. The JAK inhibitor, tofacitinib, blocks signalling for cytokines, including IL-2, IL-4, IL-7, IL-9, IL-15 and IL-21, thereby modulating immune responses. ${ }^{172}$

Tofacitinib is FDA-approved for the treatment of adults with active RA and an inadequate response or intolerance to methotrexate. In clinical studies in patients with RA, treatment with tofacitinib was associated with reductions in signs and symptoms of active disease, improvements in physical function and health-related quality of life, and slowing of radiographic progression. ${ }^{172-174}$ In addition, tofacitinib is effective in patients with RA despite concomitant treatment with csDMARDs and inhibits progression of structural damage in patients receiving methotrexate. ${ }^{175} 176$ Treatment with tofacitinib and background methotrexate was numerically similar to adalimumab in efficacy, and the combination of tofacitinib and methotrexate was effective in patients with prior inadequate response to TNF- $\alpha$ inhibitors. ${ }^{177} 178$ Also, in a head-to-head non-inferiority study of patients with RA and inadequate response to methotrexate, the combination of tofacitinib and methotrexate was non-inferior to the combination of adalimumab and methotrexate; however, tofacitinib monotherapy was not non-inferior to either combination. ${ }^{179}$

Tofacitinib also has demonstrated efficacy in patients with PsA. In the phase III Oral Psoriatic Arthritis Trial (OPAL) Broaden study of patients with PsA and prior inadequate response to csDMARDs, tofacitinib was efficacious for both PsA and psoriasis. ${ }^{180}$ Similar findings were observed in the phase III OPAL Beyond study of tofacitinib in patients with PsA and prior inadequate response to TNF- $\alpha$ inhibitors. ${ }^{181}$ The safety profile of tofacitinib was similar between patients with RA and PsA. ${ }^{174} 180$ Tofacitinib was recently approved by the FDA for the treatment of PsA. 


\section{CONCLUSIONS}

Accurate diagnosis of PsA and RA is important because, although these diseases have a number of overlapping clinical, serological and radiographic features, differences in underlying pathogenesis and response to therapy translate into substantially different clinical outcomes. An understanding of the various clinical characteristics, triggering factors, comorbidities and extra-articular manifestations of PsA and RA can aid in the determination of the correct diagnosis. Use of laboratory and imaging techniques can be particularly helpful in distinguishing between these two diseases. Once an accurate diagnosis has been made, clinicians can decide which therapy should be used to provide maximal improvements in the signs and symptoms of RA or PsA based on patient and disease characteristics.

Contributors All authors contributed equally to the content of the paper.

Funding Technical assistance with editing, figure preparation and styling of the manuscript for submission was provided by 0xford PharmaGenesis, Inc., and was funded by Novartis Pharmaceuticals Corporation.

Disclaimer The authors were fully responsible for all content and editorial decisions and received no financial support or other form of compensation related to the development of this manuscript.

Competing interests JFM is a consultant for Biogen Idec, AbbVie, Eli Lilly, Novartis, Pfizer, Janssen, UCB, Samumed, Science 37, Celgene, Sanofi Regeneron, Merck and GSK; speaker for AbbVie; an investigator for Biogen Idec, Pfizer, Sanofi Regeneron, Incyte and Novartis; licensed outcome measure to AbbVie and Lilly. LRE has no competing interests to disclose. RF has consulted and served as an investigator for AbbVie, Acea, Amgen, Augurex, BMS, Boehringer Ingelheim, Celgene, Genentech, GSK, Janssen, Eli Lilly, EMD Merck Serono, Novartis, Pfizer, Samumed, Roche, Sanofi Genzyme and UCB.

Patient consent Not required.

Provenance and peer review Not commissioned; externally peer reviewed.

Data sharing statement No additional data are available.

Open access This is an Open Access article distributed in accordance with the Creative Commons Attribution Non Commercial (CC BY-NC 4.0) license, which permits others to distribute, remix, adapt, build upon this work non-commercially, and license their derivative works on different terms, provided the original work is properly cited and the use is non-commercial. See: http://creativecommons.org/ licenses/by-nc/4.0/

(C) Article author(s) (or their employer(s) unless otherwise stated in the text of the article) 2018. All rights reserved. No commercial use is permitted unless otherwise expressly granted.

\section{REFERENCES}

1. Zabotti A, Salvin S, Quartuccio L, et al. Differentiation between early rheumatoid and early psoriatic arthritis by the ultrasonographic study of the synovio-entheseal complex of the small joints of the hands. Clin Exp Rheumatol 2016;34:459-65.

2. Verheul MK, Fearon U, Trouw LA, et al. Biomarkers for rheumatoid and psoriatic arthritis. Clinical Immunology 2015;161:2-10.

3. Turesson C. Extra-articular rheumatoid arthritis. Curr Opin Rheumatol 2013;25:360-6.

4. Villeneuve $\mathrm{E}, \mathrm{Nam} \mathrm{JL}$, Bell MJ, et al. A systematic literature review of strategies promoting early referral and reducing delays in the diagnosis and management of inflammatory arthritis. Ann Rheum Dis 2013;72:13-22.

5. Gladman DD. Clinical features and diagnostic considerations in psoriatic arthritis. Rheumatic Disease Clinics of North America 2015;41:569-79.

6. Merola JF, Wu S, Han J, et al. Psoriasis, psoriatic arthritis and risk of gout in US men and women. Ann Rheum Dis 2015;74:1495-500.

7. Merdler-Rabinowicz R, Tiosano S, Comaneshter D, et al. Comorbidity of gout and rheumatoid arthritis in a large population database. Clin Rheumatol 2017;36:657-60.
8. McGonagle D, Hermann K-GA, Tan AL. Differentiation between osteoarthritis and psoriatic arthritis: implications for pathogenesis and treatment in the biologic therapy era. Rheumatology 2015;54:29-38.

9. Firestein GS, Budd RC, Gabriel SE, et al. Kelley and Firestein's Textbook of Rheumatology. 10th edn. Philadelphia, PA: Elsevier, 2017.

10. Ritchlin CT, Colbert RA, Gladman DD. Psoriatic arthritis. N Engl J Med Overseas Ed 2017;376:957-70.

11. Behrens F, Koehm M, Thaçi D, et al. Anti-citrullinated protein antibodies are linked to erosive disease in an observational study of patients with psoriatic arthritis. Rheumatology 2016;55:1791-5

12. Helmick CG, Felson DT, Lawrence RC, et al. Estimates of the prevalence of arthritis and other rheumatic conditions in the United States: Part I. Arthritis \& Rheumatism 2008;58:15-25.

13. Gelfand JM, Gladman DD, Mease PJ, et al. Epidemiology of psoriatic arthritis in the population of the United States. J Am Acad Dermatol 2005;53:573.

14. Mease PJ, Gladman DD, Papp KA, et al. Prevalence of rheumatologist-diagnosed psoriatic arthritis in patients with psoriasis in European/North American dermatology clinics. J Am Acad Dermatol 2013;69:729-35.

15. Shichikawa K, Inoue K, Hirota S, et al. Changes in the incidence and prevalence of rheumatoid arthritis in Kamitonda, Wakayama, Japan, 1965-1996. Ann Rheum Dis 1999;58:751-6.

16. Zeng Q, Huang S, Chen R. [10-year epidemiological study on rheumatic diseases in Shantou area]. Zhonghua Nei Ke Za Zhi 1997;36:193-7.

17. Del Puente A, Knowler WC, Pettitt DJ, et al. High incidence and prevalence of rheumatoid arthritis in Pima Indians. Am J Epidemiol 1989;129:1170-8

18. Harvey J, Lotze M, Stevens MB, et al. Rheumatoid arthritis in a Chippewa Band. I. Pilot screening study of disease prevalence. Arthritis Rheum 1981;24:717-21.

19. Rudan I, Sidhu S, Papana A, et al. Prevalence of rheumatoid arthritis in low- and middle-income countries: A systematic review and analysis. J Glob Health 2015;5:010409.

20. Hunter TM, Boytsov NN, Zhang $X$, et al. Prevalence of rheumatoid arthritis in the United States adult population in healthcare claims databases, 2004-2014. Rheumatol Int 2017;37:1551-7.

21. Alamanos $Y$, Voulgari PV, Drosos AA. Incidence and prevalence of psoriatic arthritis: a systematic review. J Rheumatol 2008;35:1354-8.

22. Hukuda S, Minami M, Saito T, et al. Spondyloarthropathies in Japan: nationwide questionnaire survey performed by the Japan Ankylosing Spondylitis Society. J Rheumatol 2001;28:554-9.

23. Stastny P. Association of the B-cell alloantigen DRw4 with rheumatoid arthritis. N Engl J Med Overseas Ed 1978;298:869-71.

24. Demoruelle MK, Solomon JJ, Fischer A, et al. The lung may play a role in the pathogenesis of rheumatoid arthritis. Int J Clin Rheumtol 2014:9:295-309.

25. Scher JU, Ubeda C, Artacho A, et al. Decreased bacterial diversity characterizes the altered gut microbiota in patients with psoriatic arthritis, resembling dysbiosis in inflammatory bowel disease. Arthritis Rheumatol 2015;67:128-39.

26. Mc Ardle A, Flatley B, Pennington SR, et al. Early biomarkers of joint damage in rheumatoid and psoriatic arthritis. Arthritis Res Ther 2015;17:141.

27. Acosta Felquer ML, FitzGerald O. Peripheral joint involvement in psoriatic arthritis patients. Clin Exp Rheumatol 2015;33:S26-30.

28. Mclnnes IB, Schett $G$. The pathogenesis of rheumatoid arthritis. $N$ Engl J Med Overseas Ed 2011;365:2205-19.

29. Perera GK, Di Meglio P, Nestle FO. Psoriasis. Annu Rev Pathol 2012;7:385-422.

30. Coates LC, FitzGerald O, Helliwell PS, et al. Psoriasis, psoriatic arthritis, and rheumatoid arthritis: Is all inflammation the same? Semin Arthritis Rheum 2016;46:291-304.

31. Cafaro G, Mclnnes IB. Psoriatic arthritis: tissue-directed inflammation? Clin Rheumatol 2018;37:859-68.

32. Menon B, Gullick NJ, Walter GJ, et al. Interleukin-17+CD8+ T cells are enriched in the joints of patients with psoriatic arthritis and correlate with disease activity and joint damage progression. Arthritis Rheumatol 2014;66:1272-81.

33. Ciccia F, Guggino G, Ferrante A, et al. Interleukin-9 overexpression and Th9 polarization characterize the inflamed gut, the synovial tissue, and the peripheral blood of patients with psoriatic arthritis. Arthritis Rheumatol 2016;68:1922-31.

34. Ciccia F, Guggino G, Raimondo S, et al. IL-9 modulates adaptive immune responses in patients with psoriatic arthritis. Arthritis Rheumatol 2017;69:473-5. 
35. Demoruelle MK, Weisman MH, Simonian PL, et al. Brief report: airways abnormalities and rheumatoid arthritis-related autoantibodies in subjects without arthritis: early injury or initiating site of autoimmunity? Arthritis \& Rheumatism 2012;64:1756-61.

36. Janssen KMJ, de Smit MJ, Brouwer E, et al. Rheumatoid arthritisassociated autoantibodies in non-rheumatoid arthritis patients with mucosal inflammation: a case-control study. Arthritis Res Ther 2015;17:174.

37. Aletaha D, Neogi T, Silman AJ, et al. Rheumatoid arthritis classification criteria: an American College of Rheumatology/ European League Against Rheumatism collaborative initiative. Arthritis Rheum 2010;2010:2569-81.

38. Taylor W, Gladman D, Helliwell P, et al. Classification criteria for psoriatic arthritis: development of new criteria from a large international study. Arthritis \& Rheumatism 2006;54:2665-73.

39. Veale DJ, Fearon U. What makes psoriatic and rheumatoid arthritis so different? RMD Open 2015;1:e000025.

40. Helliwell PS, Porter G, Taylor WJ, et al. Polyarticular psoriatic arthritis is more like oligoarticular psoriatic arthritis, than rheumatoid arthritis. Ann Rheum Dis 2007;66:113-7.

41. Marchesoni A, Atzeni F, Spadaro A, et al. Identification of the clinical features distinguishing psoriatic arthritis and fibromyalgia. $J$ Rheumatol 2012;39:849-55.

42. Helliwell PS, Hetthen J, Sokoll K, et al. Joint symmetry in early and late rheumatoid and psoriatic arthritis: Comparison with a mathematical model. Arthritis \& Rheumatism 2000;43:865-71.

43. Baraliakos $X$, Coates LC, Braun J. The involvement of the spine in psoriatic arthritis. Clin Exp Rheumatol 2015;33:S31-5.

44. Joaquim AF, Appenzeller $S$. Cervical spine involvement in rheumatoid arthritis - A systematic review. Autoimmun Rev 2014;13:1195-202.

45. Leibovich SJ, Polverini PJ, Shepard HM, et al. Macrophageinduced angiogenesis is mediated by tumour necrosis factor- $\alpha$. Nature 1987;329:630-2

46. Čeponis A, Konttinen YT, Imai S, et al. Synovial lining, endothelial and inflammatory mononuclear cell proliferation in synovial membranes in psoriatic and reactive arthritis: a comparative quantitative morphometric study. Rheumatology 1998;37:170-8.

47. Reece RJ, Canete JD, Parsons WJ, et al. Distinct vascular patterns of early synovitis in psoriatic, reactive, and rheumatoid arthritis. Arthritis \& Rheumatism 1999;42:1481-4.

48. Ritchlin C, Haas-Smith SA, Hicks D, et al. Patterns of cytokine production in psoriatic synovium. J Rheumatol 1998;25:1544-52.

49. Polachek A, Li S, Chandran V, et al. Clinical enthesitis in a prospective longitudinal psoriatic arthritis cohort: Incidence, prevalence, characteristics and outcome. Arthritis Care Res 2017;69:1685-91.

50. Schett G, Lories RJ, D'Agostino M-A, et al. Enthesitis: from pathophysiology to treatment. Nat Rev Rheumatol 2017;13:731-41.

51. Naredo E, Möller I, de Miguel E, et al. High prevalence of ultrasonographic synovitis and enthesopathy in patients with psoriasis without psoriatic arthritis: a prospective case-control study. Rheumatology 2011;50:1838-48

52. Krüger K, Burmester GR, Wassenberg S, et al. THU0141 A noninterventional clinical study evaluating the use of golimumab in patients with rheumatoid arthritis (RA), psoriatic arthritis (PSA), and ankylosing spondylitis (AS) in a real-life setting in Germany. Ann Rheum Dis 2016;75(Suppl 2):232.

53. Kane Det al. A prospective, clinical and radiological study of early psoriatic arthritis: an early synovitis clinic experience. Rheumatology 2003;42:1460-8.

54. Tan AL, Benjamin M, Toumi $\mathrm{H}$, et al. The relationship between the extensor tendon enthesis and the nail in distal interphalangeal joint disease in psoriatic arthritis--a high-resolution MRI and histological study. Rheumatology 2007;46:253-6.

55. Rosenbaum JT. Uveitis in spondyloarthritis including psoriatic arthritis, ankylosing spondylitis, and inflammatory bowel disease. Clin Rheumatol 2015;34:999-1002.

56. van der Horst-Bruinsma IE, Lems WF, Dijkmans BA. A systematic comparison of rheumatoid arthritis and ankylosing spondylitis. Clin Exp Rheumatol 2009;27:S43-9

57. Zlatanović G, Veselinović D, Cekić S, et al. Ocular manifestation of rheumatoid arthritis-different forms and frequency. Bosn J Basic Med Sci 2010;10:323-7.

58. Paiva ESet al. Characterisation of uveitis in patients with psoriatic arthritis. Ann Rheum Dis 2000;59:67-70.

59. Lambert JR, Wright V. Eye inflammation in psoriatic arthritis. Ann Rheum Dis 1976;35:354-6.

60. Brewerton DA, Nicholls A, Caffrey M, et al. Acute anterior uveitis and HL-A 27. The Lancet 1973;302:994-6.
61. Turesson Cet al. Extra-articular disease manifestations in rheumatoid arthritis: incidence trends and risk factors over 46 years. Ann Rheum Dis 2003;62:722-7.

62. Makol A, Crowson CS, Wetter DA, et al. Vasculitis associated with rheumatoid arthritis: a case-control study. Rheumatology 2014;53:890-9

63. Sangueza OP, Caudell MD, Mengesha YM, et al. Palisaded neutrophilic granulomatous dermatitis in rheumatoid arthritis. J Am Acad Dermatol 2002;47:251-7.

64. Coates LC, Conaghan PG, Emery P, et al. Sensitivity and specificity of the classification of psoriatic arthritis criteria in early psoriatic arthritis. Arthritis \& Rheumatism 2012;64:3150-5.

65. Shin D, Kim HJ, Kim DS, et al. Clinical features of psoriatic arthritis in Korean patients with psoriasis: a cross-sectional observational study of 196 patients with psoriasis using psoriatic arthritis screening questionnaires. Rheumatol Int 2016;36:207-12.

66. Wilson FC, Icen M, Crowson CS, et al. Incidence and clinical predictors of psoriatic arthritis in patients with psoriasis: A population-based study. Arthritis \& Rheumatism 2009;61:233-9.

67. Merola JF, Li T, Li WQ, et al. Prevalence of psoriasis phenotypes among men and women in the USA. Clin Exp Dermatol 2016;41:486-9.

68. Popescu C, Zofotă S, Bojincă V, et al. Anti-cyclic citrullinated peptide antibodies in psoriatic arthritis-cross-sectional study and literature review. J Med Life 2013;6:376-82.

69. Vander Cruyssen B, Peene I, Cantaert T, et al. Anti-citrullinated protein/peptide antibodies (ACPA) in rheumatoid arthritis: specificity and relation with rheumatoid factor. Autoimmun Rev 2005;4:468-74

70. Shen R, Ren X, Jing R, et al. Rheumatoid factor, anti-cyclic citrullinated peptide antibody, C-reactive protein, and erythrocyte sedimentation rate for the clinical diagnosis of rheumatoid arthritis. Lab Med 2015;46:226-9.

71. Punzi L, Podswiadek M, Oliviero F, et al. Laboratory findings in psoriatic arthritis. Reumatismo 2007;59(Suppl 1):52-5.

72. Navarro-Compán V, Gherghe AM, Smolen JS, et al. Relationship between disease activity indices and their individual components and radiographic progression in RA: a systematic literature review. Rheumatology 2015;54:994-1007.

73. Lindqvist UR, Alenius GM, Husmark T, et al. The Swedish early psoriatic arthritis register-2-year followup: a comparison with early rheumatoid arthritis. J Rheumatol 2008;35:668-73.

74. Bandinelli F, Denaro V, Prignano F, et al. Ultrasonographic wrist and hand abnormalities in early psoriatic arthritis patients: correlation with clinical, dermatological, serological and genetic indices. Clin Exp Rheumatol 2015;33:330-5.

75. Dönmez S, Pamuk Ömer Nuri, Akker M, et al. Clinical features and types of articular involvement in patients with psoriatic arthritis. Clin Rheumatol 2015;34:1091-6.

76. Bitik B, Mercan R, Tufan A, et al. Differential diagnosis of elevated erythrocyte sedimentation rate and C-reactive protein levels: a rheumatology perspective. Eur J Rheumatol 2015;2:131-4.

77. Ichikawa N, Taniguchi A, Kobayashi S, et al. Performance of hands and feet radiographs in differentiation of psoriatic arthritis from rheumatoid arthritis. Int J Rheum Dis 2012;15:462-7.

78. Epis O, Paoletti F, d'Errico T, et al. Ultrasonography in the diagnosis and management of patients with inflammatory arthritides. Eur $J$ Intern Med 2014;25:103-11.

79. Wakefield RJ, Balint PV, Szkudlarek M, et al. Musculoskeletal ultrasound including definitions for ultrasonographic pathology. $J$ Rheumatol 2005;32:2485-7.

80. Ibrahim G, Groves C, Chandramohan M, et al. Clinical and ultrasound examination of the leeds enthesitis index in psoriatic arthritis and rheumatoid arthritis. ISRN Rheumatol 2011:2011:731917.

81. Wiell C, Szkudlarek M, Hasselquist M, et al. Ultrasonography, magnetic resonance imaging, radiography, and clinical assessment of inflammatory and destructive changes in fingers and toes of patients with psoriatic arthritis. Arthritis Res Ther 2007;9:R119.

82. Gutierrez M, Filippucci E, Salaffi F, et al. Differential diagnosis between rheumatoid arthritis and psoriatic arthritis: the value of ultrasound findings at metacarpophalangeal joints level. Ann Rheum Dis 2011;70:1111-4.

83. Anandarajah A. Imaging in psoriatic arthritis. Clin Rev Allergy Immunol 2013;44:157-65.

84. Chiavaras MM, Jacobson JA, Yablon CM, et al. Pitfalls in wrist and hand ultrasound. American Journal of Roentgenology 2014;203:531-40

85. Dalbeth N, Pui K, Lobo M, et al. Nail disease in psoriatic arthritis: distal phalangeal bone edema detected by magnetic resonance 
imaging predicts development of onycholysis and hyperkeratosis. $J$ Rheumatol 2012;39:841-3.

86. Forney MC, Winalski CS, Schils JP. Magnetic resonance imaging of inflammatory arthropathies of peripheral joints. Topics in Magnetic Resonance Imaging 2011;22:45-59.

87. Narváez J, Narváez JA, de Albert M, et al. Can magnetic resonance imaging of the hand and wrist differentiate between rheumatoid arthritis and psoriatic arthritis in the early stages of the disease? Semin Arthritis Rheum 2012;42:234-45.

88. Roubille C, Richer V, Starnino T, et al. Evidence-based recommendations for the management of comorbidities in rheumatoid arthritis, psoriasis, and psoriatic arthritis: expert opinion of the Canadian Dermatology-Rheumatology Comorbidity Initiative. $J$ Rheumatol 2015;42:1767-80.

89. Han C, Robinson DW, Hackett MV, et al. Cardiovascular disease and risk factors in patients with rheumatoid arthritis, psoriatic arthritis, and ankylosing spondylitis. J Rheumatol 2006;33:2167-72.

90. Labitigan M, Bahče-Altuntas A, Kremer JM, et al. Higher rates and clustering of abnormal lipids, obesity, and diabetes mellitus in psoriatic arthritis compared with rheumatoid arthritis. Arthritis Care Res 2014;66:600-7.

91. Duivenvoorden R, Mani V, Woodward M, et al. Relationship of serum inflammatory biomarkers with plaque inflammation assessed by FDG PET/CT. JACC Cardiovasc Imaging 2013;6:1087-94.

92. Haroon M, Gallagher P, Heffernan E, et al. High prevalence of metabolic syndrome and of insulin resistance in psoriatic arthritis is associated with the severity of underlying disease. $J$ Rheumatol 2014:41:1357-65.

93. Gelfand JM, Troxel AB, Lewis JD, et al. The risk of mortality in patients with psoriasis: results from a population-based study. Arch Dermatol 2007:143:1493-9.

94. Gelfand JM, Neimann AL, Shin DB, et al. Risk of myocardial infarction in patients with psoriasis. JAMA 2006;296:1735-41.

95. Miele L, Vallone S, Cefalo C, et al. Prevalence, characteristics and severity of non-alcoholic fatty liver disease in patients with chronic plaque psoriasis. J Hepatol 2009;51:778-86.

96. Nas K, Karkucak M, Durmus B, et al. Comorbidities in patients with psoriatic arthritis: a comparison with rheumatoid arthritis and psoriasis. Int J Rheum Dis 2015;18:873-9.

97. Dubreuil M, Rho YH, Man A, et al. Diabetes incidence in psoriatic arthritis, psoriasis and rheumatoid arthritis: a UK population-based cohort study. Rheumatology 2014;53:346-52.

98. Bhole VM, Choi HK, Burns LC, et al. Differences in body mass index among individuals with PsA, psoriasis, RA and the general population. Rheumatology 2012;51:552-6.

99. Husni ME. Comorbidities in psoriatic arthritis. Rheumatic Disease Clinics of North America 2015;41:677-98.

100. Lie E, van der Heijde D, Uhlig T, et al. Effectiveness and retention rates of methotrexate in psoriatic arthritis in comparison with methotrexate-treated patients with rheumatoid arthritis. Ann Rheum Dis 2010;69:671-6.

101. Coates LC, Kavanaugh A, Mease PJ, et al. Group for Research and Assessment of Psoriasis and Psoriatic Arthritis 2015 treatment recommendations for psoriatic arthritis. Arthritis Rheumatol 2016;68:1060-71.

102. Kingsley GH, Kowalczyk A, Taylor $\mathrm{H}$, et al. A randomized placebocontrolled trial of methotrexate in psoriatic arthritis. Rheumatology 2012;51:1368-77.

103. Coates LC, Helliwell PS. Methotrexate efficacy in the Tight Control in Psoriatic Arthritis study. J Rheumatol 2016;43:356-61.

104. Pincus T, Bergman MJ, Yazici Y. Limitations of clinical trials in chronic diseases: is the efficacy of methotrexate (MTX) underestimated in polyarticular psoriatic arthritis on the basis of limitations of clinical trials more than on limitations of MTX, as was seen in rheumatoid arthritis? Clin Exp Rheumatol 2015;33(5 Suppl 93):S82-93.

105. Kaltwasser JP, Nash P, Gladman D, et al. Efficacy and safety of leflunomide in the treatment of psoriatic arthritis and psoriasis: a multinational, double-blind, randomized, placebo-controlled clinical trial. Arthritis Rheum 2004:50:1939-50.

106. Catrina Al, Lampa J, Ernestam S, et al. Anti-tumour necrosis factor (TNF)-alpha therapy (etanercept) down-regulates serum matrix metalloproteinase (MMP)-3 and MMP-1 in rheumatoid arthritis. Rheumatology 2002;41:484-9.

107. Tian $\mathrm{Y}$, Yuan $\mathrm{W}$, Fujita $\mathrm{N}$, et al. Inflammatory cytokines associated with degenerative disc disease control aggrecanase-1 (ADAMTS-4) expression in nucleus pulposus cells through MAPK and NF-KB. Am J Pathol 2013;182:2310-21.

108. Maini R, St Clair EW, Breedveld F, et al. Infliximab (chimeric antitumour necrosis factor $\alpha$ monoclonal antibody) versus placebo in rheumatoid arthritis patients receiving concomitant methotrexate: a randomised phase III trial. ATTRACT Study Group. Lancet 1999:354:1932-9.

109. Weinblatt ME, Keystone EC, Furst DE, et al. Adalimumab, a fully human anti-tumor necrosis factor $\alpha$ monoclonal antibody, for the treatment of rheumatoid arthritis in patients taking concomitant methotrexate: the ARMADA trial. Arthritis Rheum 2003;48:35-45.

110. Moreland LW, Schiff MH, Baumgartner SW, et al. Etanercept therapy in rheumatoid arthritis. A randomized, controlled trial. Ann Intern Med 1999;130:478-86.

111. Keystone EC, Genovese MC, Klareskog L, et al. Golimumab, a human antibody to tumour necrosis factor $\alpha$ given by monthly subcutaneous injections, in active rheumatoid arthritis despite methotrexate therapy: the GO-FORWARD Study. Ann Rheum Dis 2009;68:789-96.

112. Keystone E, Heijde D, Mason D, et al. Certolizumab pegol plus methotrexate is significantly more effective than placebo plus methotrexate in active rheumatoid arthritis: findings of a fifty-twoweek, phase III, multicenter, randomized, double-blind, placebocontrolled, parallel-group study. Arthritis Rheum 2008;58:3319-29.

113. Graudal N, Jürgens G. Similar effects of disease-modifying antirheumatic drugs, glucocorticoids, and biologic agents on radiographic progression in rheumatoid arthritis: meta-analysis of 70 randomized placebo-controlled or drug-controlled studies, including 112 comparisons. Arthritis Rheum 2010;62:2852-63.

114. Navarro-Sarabia F, Ariza-Ariza R, Hernandez-Cruz B, et al. Adalimumab for treating rheumatoid arthritis. Cochrane Database Syst Rev 2005(3):CD005113

115. Chen YF, Jobanputra $P$, Barton $P$, et al. A systematic review of the effectiveness of adalimumab, etanercept and infliximab for the treatment of rheumatoid arthritis in adults and an economic evaluation of their cost-effectiveness. Health Technol Assess 2006;10:iii-iv, xi-xiii, 1-229.

116. Fiocco U, Sfriso $P$, Oliviero $F$, et al. Synovial effusion and synovial fluid biomarkers in psoriatic arthritis to assess intraarticular tumor necrosis factor- $\alpha$ blockade in the knee joint. Arthritis Res Ther 2010;12:R148.

117. Cañete JD, Pablos JL, Sanmartí R, et al. Antiangiogenic effects of anti-tumor necrosis factor $\alpha$ therapy with infliximab in psoriatic arthritis. Arthritis Rheum 2004:50:1636-41.

118. Goedkoop AY, Kraan MC, Picavet DI, et al. Deactivation of endothelium and reduction in angiogenesis in psoriatic skin and synovium by low dose infliximab therapy in combination with stable methotrexate therapy: a prospective single-centre study. Arthritis Res Ther 2004;6:R326-34.

119. Goedkoop AY, Kraan MC, Teunissen MB, et al. Early effects of tumour necrosis factor $\alpha$ blockade on skin and synovial tissue in patients with active psoriasis and psoriatic arthritis. Ann Rheum Dis 2004;63:769-73.

120. Ritchlin CT, Haas-Smith SA, Li P, et al. Mechanisms of TNF- $\alpha$ - and RANKL-mediated osteoclastogenesis and bone resorption in psoriatic arthritis. J Clin Invest 2003;111:821-31.

121. Kavanaugh A, Mclnnes I, Mease P, et al. Golimumab, a new human tumor necrosis factor $\alpha$ antibody, administered every four weeks as a subcutaneous injection in psoriatic arthritis: Twenty-four-week efficacy and safety results of a randomized, placebo-controlled study. Arthritis Rheum 2009;60:976-86.

122. Gorman JD, Sack KE, Davis JC. Treatment of ankylosing spondylitis by inhibition of tumor necrosis factor $\alpha$. N Engl J Med 2002;346:1349-56.

123. Molnar C, Scherer A, Baraliakos X, et al. TNF blockers inhibit spinal radiographic progression in ankylosing spondylitis by reducing disease activity: results from the Swiss Clinical Quality Management cohort. Ann Rheum Dis 2018;77:63-9.

124. Infante-Duarte C, Horton HF, Byrne MC, et al. Microbial lipopeptides induce the production of IL-17 in Th cells. J Immunol 2000;165:6107-15.

125. Song C, Luo L, Lei Z, et al. IL-17-producing alveolar macrophages mediate allergic lung inflammation related to asthma. J Immunol 2008;181:6117-24.

126. Lin AM, Rubin CJ, Khandpur R, et al. Mast cells and neutrophils release IL-17 through extracellular trap formation in psoriasis. $J$ Immunol 2011;187:490-500.

127. Dhodapkar KM, Barbuto S, Matthews $P$, et al. Dendritic cells mediate the induction of polyfunctional human IL17-producing cells (Th17-1 cells) enriched in the bone marrow of patients with myeloma. Blood 2008;112:2878-85.

128. Passos ST, Silver JS, O'Hara AC, et al. IL-6 promotes NK cell production of IL-17 during toxoplasmosis. J Immunol 2010;184:1776-83

129. Ortega C, Fernández-A S, Carrillo JM, et al. IL-17-producing $\mathrm{CD}^{+} \mathrm{T}$ lymphocytes from psoriasis skin plaques are cytotoxic 
effector cells that secrete Th17-related cytokines. J Leukoc Biol 2009;86:435-43.

130. Numasaki M, Fukushi J, Ono M, et al. Interleukin-17 promotes angiogenesis and tumor growth. Blood 2003;101:2620-7.

131. Yago T, Nanke $\mathrm{Y}$, Ichikawa $\mathrm{N}$, et al. IL-17 induces osteoclastogenesis from human monocytes alone in the absence of osteoblasts, which is potently inhibited by anti-TNF- $\alpha$ antibody: a novel mechanism of osteoclastogenesis by IL-17. J Cell Biochem 2009;108:947-55.

132. Meng F, Wang K, Aoyama T, et al. Interleukin-17 signaling in inflammatory, Kupffer cells, and hepatic stellate cells exacerbates liver fibrosis in mice. Gastroenterology 2012;143:765-76.

133. Hwang SY, Kim JY, Kim KW, et al. IL-17 induces production of IL-6 and IL-8 in rheumatoid arthritis synovial fibroblasts via NF-kappaB and PI3-kinase/Akt-dependent pathways. Arthritis Res Ther 2004;6:R120-8

134. Sato K, Suematsu A, Okamoto K, et al. Th17 functions as an osteoclastogenic helper T cell subset that links T cell activation and bone destruction. J Exp Med 2006;203:2673-82.

135. Adamopoulos IE, Chao CC, Geissler R, et al. Interleukin-17A upregulates receptor activator of NF-kappaB on osteoclast precursors. Arthritis Res Ther 2010;12:R29.

136. Mease PJ, Mclnnes IB, Kirkham B, et al. Secukinumab inhibition of interleukin-17A in patients with psoriatic arthritis. N Engl J Med 2015;373:1329-39.

137. Mclnnes IB, Mease PJ, Kirkham B, et al. Secukinumab, a human anti-interleukin-17A monoclonal antibody, in patients with psoriatic arthritis (FUTURE 2): a randomised, double-blind, placebocontrolled, phase 3 trial. Lancet 2015;386:1137-46.

138. van der Heijde D, Gladman DD, Kishimoto M, et al. Efficacy and safety of ixekizumab in patients with active psoriatic arthritis: 52-week results from a phase III study (SPIRIT-P1). J Rheumatol 2018;45:367-77.

139. Nash P, Kirkham B, Okada M, et al. Ixekizumab for the treatment of patients with active psoriatic arthritis and an inadequate response to tumour necrosis factor inhibitors: results from the 24-week randomised, double-blind, placebo-controlled period of the SPIRIT-P2 phase 3 trial. Lancet 2017;389:2317-27.

140. Mease PJ, van der Heijde D, Ritchlin CT, et al. Ixekizumab, an interleukin-17A specific monoclonal antibody, for the treatment of biologic-naive patients with active psoriatic arthritis: results from the 24-week randomised, double-blind, placebo-controlled and active (adalimumab)-controlled period of the phase III trial SPIRIT-P1. Ann Rheum Dis 2017;76:79-87.

141. Genovese MC, Durez P, Richards HB, et al. Efficacy and safety of secukinumab in patients with rheumatoid arthritis: a phase II, dosefinding, double-blind, randomised, placebo controlled study. Ann Rheum Dis 2013;72:863-9.

142. Genovese MC, Greenwald M, Cho CS, et al. A phase II randomized study of subcutaneous ixekizumab, an anti-interleukin-17 monoclonal antibody, in rheumatoid arthritis patients who were naive to biologic agents or had an inadequate response to tumor necrosis factor inhibitors. Arthritis Rheumatol 2014;66:1693-704.

143. Tlustochowicz W, Rahman P, Seriolo B, et al. Efficacy and safety of subcutaneous and intravenous loading dose regimens of secukinumab in patients with active rheumatoid arthritis: results from a randomized phase II study. J Rheumatol 2016;43:495-503.

144. Athie-Morales V, Smits HH, Cantrell DA, et al. Sustained IL12 signaling is required for Th1 development. J Immunol 2004;172:61-9.

145. Fulton SA, Johnsen JM, Wolf SF, et al. Interleukin-12 production by human monocytes infected with Mycobacterium tuberculosis: role of phagocytosis. Infect Immun 1996;64:2523-31.

146. D'Andrea A, Rengaraju M, Valiante NM, et al. Production of natural killer cell stimulatory factor (interleukin 12) by peripheral blood mononuclear cells. J Exp Med 1992;176:1387-98.

147. Roses RE, Xu S, Xu M, et al. Differential production of IL-23 and IL12 by myeloid-derived dendritic cells in response to TLR agonists. $\mathrm{J}$ Immunol 2008;181:5120-7.

148. Stritesky GL, Yeh N, Kaplan MH. IL-23 promotes maintenance but not commitment to the Th17 lineage. J Immunol 2008;181:5948-55.

149. Sun JC, Madera S, Bezman NA, et al. Proinflammatory cytokine signaling required for the generation of natural killer cell memory. $J$ Exp Med 2012;209:947-54.

150. Ferlazzo G, Pack M, Thomas D, et al. Distinct roles of IL-12 and IL-15 in human natural killer cell activation by dendritic cells from secondary lymphoid organs. Proc Natl Acad Sci U S A 2004;101:16606-11.

151. Adamopoulos IE, Tessmer M, Chao CC, et al. IL-23 is critical for induction of arthritis, osteoclast formation, and maintenance of bone mass. J Immunol 2011;187:951-9.
152. Kavanaugh A, Ritchlin C, Rahman P, et al. Ustekinumab, an anti-IL-12/23 p40 monoclonal antibody, inhibits radiographic progression in patients with active psoriatic arthritis: results of an integrated analysis of radiographic data from the phase 3 , multicentre, randomised, double-blind, placebocontrolled PSUMMIT-1 and PSUMMIT-2 trials. Ann Rheum Dis 2014:73:1000-6.

153. Kavanaugh A, Puig L, Gottlieb AB, et al. Maintenance of clinical efficacy and radiographic benefit through two years of ustekinumab therapy in patients with active psoriatic arthritis: results from a randomized, placebo-controlled phase III trial. Arthritis Care Res 2015;67:1739-49.

154. ClinicalTrials.gov. 2017.A study of the effectiveness and safety of ustekinumab (STELARA) and CNTO 1959 administered under the skin of patients with active rheumatoid arthritis, despite existing methotrexate therapy https://clinicaltrials.gov/ct2/show/ NCT01645280 (cited 10 Aug 2017).

155. Smolen JS, Agarwal SK, llivanova E, et al. A randomised phase II study evaluating the efficacy and safety of subcutaneously administered ustekinumab and guselkumab in patients with active rheumatoid arthritis despite treatment with methotrexate. Ann Rheum Dis 2017;76:831-9.

156. Deodhar A, Gottlieb A, Boehncke WH, et al. Efficacy and safety results of guselkumab, an anti-il23 monoclonal antibody, in patients with active psoriatic arthritis over 24 weeks: a phase 2a, randomized, double-blind, placebo-controlled study [abstract]. Ann Rheum Dis 2017;76(Suppl 2):142-3. Abstract OP0218.

157. Mease PJ, Kellner $\mathrm{H}$, Morita A. Efficacy and safety results from a phase 2 trial of risankizumab, a selective IL-23p19 inhibitor, in patients with active psoriatic arthritis [abstract]. Arthritis Rheum 2017;69(Suppl 10):Abstract 2L.

158. Li MO, Wan YY, Flavell RA. T cell-produced transforming growth factor-beta1 controls T cell tolerance and regulates Th1- and Th17cell differentiation. Immunity 2007;26:579-91.

159. Bettelli E, Carrier Y, Gao W, et al. Reciprocal developmental pathways for the generation of pathogenic effector $\mathrm{TH} 17$ and regulatory T cells. Nature 2006;441:235-8.

160. Celis R, Planell N, Fernández-Sueiro JL, et al. Synovial cytokine expression in psoriatic arthritis and associations with lymphoid neogenesis and clinical features. Arthritis Res Ther 2012;14:R93.

161. Thompson C, Davies R, Choy E. Anti cytokine therapy in chronic inflammatory arthritis. Cytokine 2016;86:92-9.

162. Mease PJ, Gottlieb AB, Berman A, et al. The efficacy and safety of clazakizumab, an anti-interleukin-6 monoclonal antibody, in a phase Ilb study of adults with active psoriatic arthritis. Arthritis Rheumatol 2016;68:2163-73.

163. Costa L, Caso F, Cantarini L, et al. Efficacy of tocilizumab in a patient with refractory psoriatic arthritis. Clin Rheumatol 2014;33:1355-7.

164. Dayer JM, de Rochemonteix B, Burrus B, et al. Human recombinant interleukin 1 stimulates collagenase and prostaglandin $\mathrm{E}_{2}$ production by human synovial cells. $J$ Clin Invest 1986;77:645-8.

165. Rooney M, Symons JA, Duff GW. Interleukin 1 beta in synovial fluid is related to local disease activity in rheumatoid arthritis. Rheumato Int 1990;10:217-9.

166. Toussirot É. Biologics in spondyloarthritis: TNF $\alpha$ inhibitors and other agents. Immunotherapy 2015;7:669-81.

167. Kremer JM, Genant HK, Moreland LW, et al. Effects of abatacept in patients with methotrexate-resistant active rheumatoid arthritis: a randomized trial. Ann Intern Med 2006;144:865-76.

168. Genovese MC, Schiff M, Luggen M, et al. Efficacy and safety of the selective co-stimulation modulator abatacept following 2 years of treatment in patients with rheumatoid arthritis and an inadequate response to anti-tumour necrosis factor therapy. Ann Rheum Dis 2008:67:547-54.

169. Mease P, Gottlieb A, van der Heijde D. Abatacept in the treatment of active psoriatic arthritis: 24-week results from a phase III study [abstract]. Arthritis Rheumatol 2016;68(Suppl 10):Abstract 1041.

170. Aletaha D, Alasti F, Smolen JS. Rituximab dissociates the tight link between disease activity and joint damage in rheumatoid arthritis patients. Ann Rheum Dis 2013;72:7-12.

171. Kang EJ, Kavanaugh A. Psoriatic arthritis: latest treatments and their place in therapy. Ther Adv Chronic Dis 2015;6:194-203.

172. Kavanaugh A, Mease PJ, Gomez-Reino JJ, et al. Longterm (52-week) results of a phase III randomized, controlled trial of apremilast in patients with psoriatic arthritis. J Rheumatol 2015;42:479-88.

173. Kavanaugh A, Mease PJ, Gomez-Reino JJ, et al. Treatment of psoriatic arthritis in a phase 3 randomised, placebo-controlled trial with apremilast, an oral phosphodiesterase 4 inhibitor. Ann Rheum Dis 2014:73:1020-6. 
174. McCann FE, Palfreeman AC, Andrews M, et al. Apremilast, a novel PDE4 inhibitor, inhibits spontaneous production of tumour necrosis factor-alpha from human rheumatoid synovial cells and ameliorates experimental arthritis. Arthritis Res Ther 2010;12:R107.

175. Genovese MC, Jarosova K, Cieślak D, et al. Apremilast in patients with active rheumatoid arthritis: A phase II, multicenter, randomized, double-blind, placebo-controlled, parallel-group study. Arthritis Rheumatol 2015;67:1703-10.

176. Fleischmann R, Kremer J, Cush J, et al. Placebo-controlled trial of tofacitinib monotherapy in rheumatoid arthritis. $N$ Engl J Med 2012;367:495-507.

177. Wallenstein GV, Kanik KS, Wilkinson B, et al. Effects of the ora Janus kinase inhibitor tofacitinib on patient-reported outcomes in patients with active rheumatoid arthritis: results of two Phase 2 randomised controlled trials. Clin Exp Rheumatol 2016:34:430-42.

178. Lee EB, Fleischmann R, Hall S, et al. Tofacitinib versus methotrexate in rheumatoid arthritis. N Engl J Med 2014;370:2377-86.

179. Kremer J, Li ZG, Hall S, et al. Tofacitinib in combination with nonbiologic disease-modifying antirheumatic drugs in patients with active rheumatoid arthritis: a randomized trial. Ann Intern Med 2013:159:253-61.

180. van der Heijde D, Tanaka Y, Fleischmann R, et al. Tofacitinib (CP-690,550) in patients with rheumatoid arthritis receiving methotrexate: twelve-month data from a twenty-four-month phase III randomized radiographic study. Arthritis Rheum 2013;65:559-70.
181. Burmester GR, Blanco R, Charles-Schoeman C, et al. Tofacitinib (CP-690,550) in combination with methotrexate in patients with active rheumatoid arthritis with an inadequate response to tumour necrosis factor inhibitors: a randomised phase 3 trial. Lancet 2013:381:451-60.

182. van Vollenhoven RF, Fleischmann R, Cohen S, et al. Tofacitinib or adalimumab versus placebo in rheumatoid arthritis. $N$ Engl J Med 2012;367:508-19.

183. Fleischmann R, Mysler E, Hall S, et al. Efficacy and safety of tofacitinib monotherapy, tofacitinib with methotrexate, and adalimumab with methotrexate in patients with rheumatoid arthritis (ORAL Strategy): a phase 3b/4, double-blind, head-to-head, randomised controlled trial. Lancet 2017;390:457-68.

184. Mease PJ, Hall S, FitzGerald O, et al. Efficacy and safety of tofacitinib, an oral janus kinase inhibitor, or adalimumab in patients with active psoriatic arthritis and an inadequate response to conventional synthetic DMARDs: A randomized, placebo-controlled, phase 3 trial [abstract]. Arthritis Rheumatol 2016;68(Suppl 10):Abstract 2983

185. Gladman DD, Rigby W, Azevedo VF, et al. Efficacy and safety of tofacitinib, an oral janus kinase inhibitor, in patients with active psoriatic arthritis and an inadequate response to tumor necrosis factor inhibitors: OPAL Beyond, a randomized, double blind, placebo-controlled, phase 3 trial [abstract]. Arthritis Rheumatol 2016;68(Suppl 10):Abstract 10L. 